\title{
Fossil fern rhizomes as a model system for exploring epiphyte community structure across geologic time: Evidence from Patagonia
}

\author{
Alexander C Bippus ${ }^{\text {Corresp., }}{ }^{1}$, Ignacio H. Escapa ${ }^{2}$, Peter Wilf $^{3}$, Alexandru M. F. Tomescu ${ }^{4}$ \\ ${ }^{1}$ Department of Botany and Plant Pathology, Oregon State University, Corvallis, Oregon, United States \\ 2 Consejo Nacional de Investigaciones Cientificas y Tecnicas (CONICET), Museo Paleontologico Egidio Feruglio, Trelew, Argentina \\ 3 Department of Geosciences, Pennsylvania State University, University Park, PA, United States \\ 4 Department of Biological Sciences, Humboldt State University, Arcata, CA, United States \\ Corresponding Author: Alexander C Bippus \\ Email address: bippusa@oregonstate.edu
}

Background. In extant ecosystems, complex networks of ecological interactions between organisms can be readily studied. In contrast, understanding of such interactions in ecosystems of the geologic past is incomplete. Specifically, in past terrestrial ecosystems we know comparatively little about plant biotic interactions besides saprotrophy, herbivory, mycorrhizal associations, and oviposition. Due to taphonomic biases, epiphyte communities are particularly rare in the plant-fossil record, despite their prominence in modern ecosystems. Accordingly, little is known about how terrestrial epiphyte communities have changed across geologic time. Here, we describe a tiny in situ fossil epiphyte community that sheds light on plant-animal and plant-plant interactions more than 50 million years ago.

Methods. A single silicified Todea (Osmundaceae) rhizome from a new locality of the early Eocene (ca. $52 \mathrm{Ma}$ ) Tufolitas Laguna del Hunco (Patagonia, Argentina) was studied in serial thin sections using light microscopy. The community of organisms colonizing the tissues of the rhizome was characterized by identifying the organisms and mapping and quantifying their distribution. A $200 \times 200 \mu \mathrm{m}$ grid was superimposed onto the rhizome cross section, and the colonizers present at each node of the grid were tallied.

Results. Preserved in situ, this community offers a rare window onto aspects of ancient ecosystems usually lost to time and taphonomic processes. The community is surprisingly diverse and includes the first fossilized leafy liverworts in South America, also marking the only fossil record of leafy bryophyte epiphytes outside of amber deposits; as well as several types of fungal hyphae and spores; microsclerotia with possible affinities in several ascomycete families; and evidence for oribatid mites.

Discussion. The community associated with the Patagonian rhizome enriches our understanding of terrestrial epiphyte communities in the distant past and adds to a growing body of literature on osmundaceous rhizomes as important hosts for component communities in ancient ecosystems, just as they are today. Because osmundaceous rhizomes represent an ecological niche that has remained virtually unchanged over time and space and are abundant in the fossil record, they provide a paleoecological model system that could be used to explore epiphyte community structure through time. 
1 Fossil fern rhizomes as a model system for exploring epiphyte community structure across 2 geologic time: Evidence from Patagonia

3 Alexander C. Bippus ${ }^{1}$, Ignacio H. Escapa ${ }^{2}$, Peter Wilf ${ }^{3}$ and Alexandru M.F. Tomescu ${ }^{4}$

4

5

6 'Department of Botany and Plant Pathology, Oregon State University, Corvallis, OR, 97331, 7 USA

$8 \quad{ }^{2}$ Consejo Nacional de Investigaciones Cientificas y Tecnicas (CONICET), Museo Paleontologico

9 Egidio Feruglio, Avenida Fontana 140, 9100, Trelew, Chubut, Argentina

$10{ }^{3}$ Department of Geosciences, Pennsylvania State University, University Park, PA 16802, USA

$11{ }^{4}$ Department of Biological Sciences, Humboldt State University, Arcata, CA 95521, USA

12

13

Author for correspondence Alexander C. Bippus

15

Email: bippusa@oregonstate.edu, phone: (209) 712-4775

16 
17 Abstract

18 Background.

In extant ecosystems, complex networks of ecological interactions between organisms can be readily studied. In contrast, understanding of such interactions in ecosystems of the geologic past is incomplete. Specifically, in past terrestrial ecosystems we know comparatively little about plant biotic interactions besides saprotrophy, herbivory, mycorrhizal associations, and oviposition. Due to taphonomic biases, epiphyte communities are particularly rare in the plantfossil record, despite their prominence in modern ecosystems. Accordingly, little is known about how terrestrial epiphyte communities have changed across geologic time. Here, we describe a tiny in situ fossil epiphyte community that sheds light on plant-animal and plant-plant interactions more than 50 million years ago.

Methods.

A single silicified Todea (Osmundaceae) rhizome from a new locality of the early Eocene (ca. 52 Ma) Tufolitas Laguna del Hunco (Patagonia, Argentina) was studied in serial thin sections using light microscopy. The community of organisms colonizing the tissues of the rhizome was characterized by identifying the organisms and mapping and quantifying their distribution. A $200 \times 200 \mu \mathrm{m}$ grid was superimposed onto the rhizome cross section, and the colonizers present at each node of the grid were tallied.

\section{Results.}

Preserved in situ, this community offers a rare window onto aspects of ancient ecosystems usually lost to time and taphonomic processes. The community is surprisingly diverse and includes the first fossilized leafy liverworts in South America, also marking the only fossil record of leafy bryophyte epiphytes outside of amber deposits; as well as several types of fungal hyphae and spores; microsclerotia with possible affinities in several ascomycete families; and evidence for oribatid mites.

\section{Discussion.}

The community associated with the Patagonian rhizome enriches our understanding of terrestrial epiphyte communities in the distant past and adds to a growing body of literature on osmundaceous rhizomes as important hosts for component communities in ancient ecosystems, just as they are today. Because osmundaceous rhizomes represent an ecological niche that has remained virtually unchanged over time and space and are abundant in the fossil record, they 
48 provide a paleoecological model system that could be used to explore epiphyte community

49 structure through time.

\section{Introduction}

In the modern biota, direct access to living organisms has revealed significant portions of

their networks of ecological interactions. In contrast, understanding of such interactions is vastly incomplete in ecosystems of the geologic past. Here, we investigate a complex community of organisms that lived in association with an osmundaceous fern, preserved in Eocene rocks (ca. $52 \mathrm{Ma}$ ) of the Huitrera Formation, Argentinean Patagonia. The Huitrera Formation hosts one of the most diverse Eocene floras characterized to date (Wilf et al., 2003, 2005a), yet the interactions of plants in this flora with other organisms are just beginning to be characterized (e.g., Wilf et al., 2005b). The fossil community associated with the osmundaceous fern is surprisingly diverse and includes the first fossil epiphytic liverworts known outside of amber deposits. Preserved in situ, this community offers a rare window onto aspects of ancient ecosystems usually lost to time and taphonomic processes. Such ecologically relevant aspects of community dynamics (abundance and diversity of epiphytes and incidence of herbivory), typically unavailable for fossil associations, are described here. Rather than describing in detail the biotic interactions between members of this community, here we aim to provide an assessment of epiphyte community structure. We also use a broad definition of epiphyte, which encompasses all organisms that live on a host plant (Steel and Bastow Wilson, 2003). Together, the fossils represent a tiny epiphyte community centered around a single host plant.

\section{Materials and Methods}

\section{$\underline{\text { Geologic setting }}$}

The fossils described here come from a new site ca. $2.1 \mathrm{~km}$ south of the Chubut River and $9.8 \mathrm{~km}$ due west of Piedra Parada in northwestern Chubut Province, Patagonian Argentina, S 4239'20.60", W 70¹3'22.20". The source strata belong to the Tufolitas Laguna del Hunco, an early Eocene, volcaniclastic, lacustrine caldera-fill deposit of the Huitrera Formation that is embedded in the Middle Chubut River Volcanic-Pyroclastic Complex (Aragón and Mazzoni, 1997). The new fossil site sits in the southern exposure area of the Tufolitas Laguna del Hunco, ca. $24 \mathrm{~km} \mathrm{SSW}$ of the well-known Laguna del Hunco fossil locality (Berry, 1925; Petersen, 
1946; Wilf et al., 2003), which lies in the northeastern exposures of the same extensive, highly fossiliferous unit. In this southern area, an ignimbrite that caps the fossil lake bed exposures ca. $5 \mathrm{~km}$ east of the new fossil site yielded an ${ }^{40} \mathrm{Ar}-{ }^{39} \mathrm{Ar}$ age on plagioclase of $49.26 \pm 0.56 \mathrm{Ma}$ (early Eocene, Ypresian) in an unpublished thesis (Gosses, 2006; Gosses et al., 2006), directly providing a minimum age for the osmundaceous rhizome. We note that this age has not been subsequently vetted or revised for updated decay constants (Kuiper et al., 2008), but it is likely to be broadly accurate because it lies in correct stratigraphic order relative to other dated samples from the Eocene caldera system (Gosses, 2006; Gosses et al., 2006; Tejedor et al., 2009).

At Laguna del Hunco (northeastern exposures), three ${ }^{40} \mathrm{Ar}-{ }^{39} \mathrm{Ar}$ ages from volcanic ashes and two recorded paleomagnetic reversals, all from strata located within the main fossiliferous section of the Tufolitas Laguna del Hunco, constrain the time of fossil deposition there to the early Eocene as well (Wilf et al., 2003, 2005a). The most reliable radiometric age at Laguna del Hunco, on sanidines from an ash taken from the middle of the most densely sampled fossiliferous interval and analyzed in two different labs, is $52.22 \pm 0.22 \mathrm{Ma}$ (early Eocene, Ypresian) following recalibration for modern decay constants (Wilf et al., 2003, 2005a, 2017; Kuiper et al., 2008; Wilf, 2012). Thus, the osmundaceous rhizome can safely be considered Ypresian and in the age range of ca. 49.3 to ca. 52.2 Ma. We prefer the older end of this range because the dates from Laguna del Hunco, despite their ca. $24 \mathrm{~km}$ geographic distance from the new fossil site, come from tuffs located within the Tufolitas Laguna del Hunco, the same unit that holds the osmundaceous rhizome fossil. The dated ignimbrite in the southern area (Gosses, 2006; Gosses et al., 2006) lies above that unit.

At Laguna del Hunco itself, the Tufolitas Laguna del Hunco host one of the most diverse Eocene compression floras known (Wilf et al., 2003, 2005a). The flora has a robust Gondwanic component displayed among its gymnosperm and angiosperm species, as described extensively elsewhere; among the most striking occurrences are the well-preserved and abundant fossils of Agathis (Araucariaceae) and Eucalyptus (Myrtaceae) Gandolfo et al., 2011; Wilf et al., 2013, 2014).

\section{The host fern}

The host plant is a permineralized osmundaceous fern rhizome ca. $8 \mathrm{~cm}$ in diameter and $20 \mathrm{~cm}$ tall. This rhizome specimen and associated sterile foliage collected from the same locality 
110 were recently described as Todea $\mathrm{cf}$. T. amissa M. Carvalho (Bomfleur and Escapa, 2019), a

111 species initially described based on compressions of sterile and fertile foliage from the

112 northeastern exposures of Laguna del Hunco (Carvalho et al., 2013). The two records of Todea

113 in the Tufolitas Laguna del Hunco comprise the only South American fossil or extant record of

114 the genus (extant in Australia, New Guinea, and southern Africa; Carvalho et al., 2013).

115

116 Methods

117 The Todea rhizome was studied in serial thin sections using light microscopy.

118 Photographs of whole thin sections were taken using a light box and a Canon EOS 70D Camera

119 fitted with a Canon 60mm macro lens and were stitched together using Photoshop CC (Adobe,

120 San Jose, California, USA). All other micrographs were taken using a Nikon Coolpix E8800

121 digital camera mounted on a Nikon Eclipse E400 microscope and processed using Photoshop

122 CC. All specimens and preparations are housed in the collections of the Museo Paleontologico

123 Egidio Feruglio (MPEF-Pb), Trelew, Argentina, under catalog number MPEF-Pb 9299. The

124 distribution of colonizing organisms in fern tissue was quantified by superimposing a $200 \mu \mathrm{m} \mathrm{x}$

$125200 \mu \mathrm{m}$ grid onto the cross section of the rhizome (Fig. 1). At each intersection of the grid, we

126 recorded the type of fern tissue and the presence and types of colonizers. This process yielded

1273,820 data points for the entire rhizome cross section. Of these, 252 data points included

128 colonizing organisms (see Table 1).

129

130

131

\section{Results}

Epiphytic plants

132

More than 25 small leafy shoots are found, primarily along the outer perimeter on one side of the rhizome, but also between leaf bases elsewhere along the rhizome (Fig. 1). The leafy shoots are up to $3.75 \mathrm{~mm}$ long and $230-410 \mu \mathrm{m}$ in diameter. They exhibit pinnate branching, with branches $>200 \mu \mathrm{m}$ long, diverging at 450-850 $\mu \mathrm{m}$ intervals (Fig. 2B-C). Stems are 30-180 $\mu \mathrm{m}$ in diameter, comprised entirely of isodiametric to oval parenchyma cells $10-22 \mu \mathrm{m}$ across and 55-78 $\mu \mathrm{m}$ long (Fig. 2B). Leaves are two-ranked and attached at 10-45 $\mu \mathrm{m}$ intervals (Fig. 2A). Incompletely preserved, they are at least $490 \mu \mathrm{m}$ long, lack a midrib, and are inserted at $30-40^{\circ}$ angles (Fig. 2A-B). Their thickness $(7.5-12.5 \mu \mathrm{m})$ indicates that they are probably unistratose. 
Additionally, a small root was found in the detritus at the periphery of the rhizome (Fig.

142 1). The root is $0.7 \mathrm{~mm}$ in diameter and has a diarch protostele ca. $100 \mu \mathrm{m}$ wide (Fig. 2D).

143 Secondary xylem with narrow $(10-21 \mu \mathrm{m})$ tracheids (Fig. 2D) comprise ca. $75 \%$ of the root;

144 some bark is also preserved (Fig. 2D).

145

146

147

148

149

150

151

152

153

154

155

156

157

158

159

160

161

162

163

164

165

166

167

168

169

170

171

Fungi

Fungal hyphae are abundant in highly degraded parts of the rhizome and in surrounding plant detritus (Fig. 1, 2L). They fall into two types: (1) smaller, apparently aseptate hyphae 1.5$2.0 \mu \mathrm{m}$ in diameter; and (2) larger, septate hyphae 3.0-5.0 $\mu \mathrm{m}$ in diameter (Fig. 2L). The latter have septae spaced at 21-22 $\mu \mathrm{m}$; clamp connections were not observed.

Darkly pigmented, round to oval cerebriform microsclerotia are also abundant in highly degraded parts of the rhizome and in the associated plant detritus (Fig. 1). The microsclerotia are 42-50 $\mu \mathrm{m}$ in diameter and composed of isodiametric to oval cells 4-12 $\mu \mathrm{m}$ in size (Fig. 2F).

Five other types of dispersed fungal reproductive structures are present in detritus associated with the rhizome (Fig. 1, 2G-K). These reproductive structures are multicellular (three to eight celled), uniseriate, more-or-less linear spores lacking obvious pores (Fig. 2G-K); four of the five types are preserved with narrow stalks (Fig. 2G, 2H-K). Type one consists of stalked, three-celled spores (Fig. $2 \mathrm{G}$ ) ca. $15 \mu \mathrm{m}$ long x $6 \mu \mathrm{m}$ wide. The apical cell is rounded, 4 $\mu \mathrm{m}$ long x $6 \mu \mathrm{m}$ wide. The middle cell is smaller, rectangular, $3 \mu \mathrm{m}$ long x $6 \mu \mathrm{m}$ wide. The basal cell is $>10 \mu \mathrm{m}$ long and $6 \mu \mathrm{m}$ wide, tapering basally into a stalk $4 \mu \mathrm{m}$ wide. Type two includes three celled, stalked spores roughly elliptical in shape, ca. $40 \mu \mathrm{m}$ long and up to $16 \mu \mathrm{m}$ wide (Fig. $2 \mathrm{~K}$ ). The apical cell is shaped like a truncated ellipse, $18 \mu \mathrm{m}$ long and $16 \mu \mathrm{m}$ wide. The subapical cell is rectangular, $11 \mu \mathrm{m}$ long x $16 \mu \mathrm{m}$ wide. The basal cell is trapezoidal, $6 \mu \mathrm{m}$ long and $13 \mu \mathrm{m}$ wide apically, tapering to $6 \mu \mathrm{m}$ basally. The stalk tapers to $4 \mu \mathrm{m}$. Type three consists of elongate, stalked, 7- or 8-celled spores ca. $35 \mu \mathrm{m}$ long and $6 \mu \mathrm{m}$ wide (Fig. 2H). Cells, except for the basal and apical ones, are rectangular, 3-5 $\mu \mathrm{m}$ long x $6 \mu \mathrm{m}$ wide. The apical cell is rectangular-trapezoidal and slightly smaller, $2 \mu \mathrm{m}$ long x $5 \mu \mathrm{m}$ wide. The basal cell is also smaller, rectangular-trapezoidal, $3.5 \mu \mathrm{m}$ long x $4 \mu \mathrm{m}$ wide. The stalk tapers to $2 \mu \mathrm{m}$. Type four is the most abundant fungal spore, three-celled, stalked and spatulate, ca. 25-30 $\mu \mathrm{m}$ long and 15 $\mu \mathrm{m}$ wide (Fig. 2J). The apical cell is round, 13-17 $\mu \mathrm{m}$ in diameter. The middle cell is small and rectangular, 5-7 $\mu \mathrm{m}$ long $\times$ 7-8 $\mu \mathrm{m}$ wide. The basal cell is rectangular-trapezoidal, $8 \mu \mathrm{m}$ long 
172 and $7 \mu \mathrm{m}$ wide apically, tapering to $5 \mu \mathrm{m}$ basally. The stalk tapers to $3-4 \mu \mathrm{m}$. Type five consists 173 of slightly curved chains of five cells, ca. $38 \mu \mathrm{m}$ long and $9 \mu \mathrm{m}$ wide (Fig. 2I). The apical cell is 174 rounded, $8 \mu \mathrm{m}$ long and $6 \mu \mathrm{m}$ wide. The sub-apical cell is inflated, $7 \mu \mathrm{m}$ long $\mathrm{x} 9 \mu \mathrm{m}$ wide. The 175 third cell is rectangular-trapezoidal, $7 \mu \mathrm{m}$ long x $5 \mu \mathrm{m}$ wide, tapering to $4 \mu \mathrm{m}$. The fourth cell is 176 rectangular, $6 \mu \mathrm{m}$ long $\mathrm{x} 4 \mu \mathrm{m}$ wide. The basal cell is square, $4 \mu \mathrm{m}$ across.

177

178 Coprolites

179 Small, spherical to ovoid coprolites occur towards the periphery of the rhizome, in 180 excavations of the parenchymatous mesophyll, fiber band, and vascular tissue (Fig. 1, 2E).

181 Coprolites also occur externally to fern tissues, around highly degraded portions of the rhizome 182 (Fig. 1). They have smooth surfaces and are 23-260 $\mu \mathrm{m}$ in diameter, composed of angular cell183 wall fragments and opaque bodies (Fig. 2E).

184

Minute spherical structures

The degraded portions of the rhizome have groups of cells that are filled with small, spherical structures 2-6 $\mu \mathrm{m}$ in diameter (Fig. 2M). These structures occur in cells of all tissue types (parenchymatous leaf base mesophyll, fiber band, and vascular tissue; Table 1).

\section{Discussion}

\section{$\underline{\text { Taxonomic affinities of epiphytes }}$}

Small epiphytic plants

The small size of these plants and their lack of conducting tissues indicate that they are bryophytes. The only bryophyte group that combines pinnately branched gametophytes with two-ranked leaves that are unistratose, lack a midrib, and are inserted at wide angles to the stem are leafy liverworts (Schofield, 1985). The incomplete preservation of the leaves, which typically provide taxonomically informative characters among liverworts, precludes a narrower systematic placement of these plants.

Root 
202

203

204

205

206

207

208

209

210

211

212

213

214

215

216

217

218

219

220

221

222

223

224

225

226

227

228

229

230

231

232

The diarch primary xylem and high proportion of secondary xylem, lacking vessels, are features typical of gymnosperms (Esau, 1965).

\section{Fungi}

The microsclerotia documented here are similar in size and morphology to the cerebriform microsclerotia described in the roots of Eorhiza arnoldii Robison et Person from the Eocene of Canada, which were attributed to dark, septate endophytes belonging to a lineage of dematiaceous ascomycetes (Klymiuk, Taylor \& Taylor, 2013b).

Type one spores compare in overall morphology to smaller members of the dispersed fossil spore genus Diporicellaesporites Elsik, especially D. minisculus Sheffy et Dilcher, but the pores diagnostic of this genus (Kalgutkar \& Jansonius, 2000) are not observable in the Argentinean material. Type two and four spores are comparable to species of the dispersed spore genus Brachysporites Lange et Smith, whose multicellular, usually spatulate spores resemble conidia of the extant dematiaceous ascomycete genus Brachysporium Saccardo (Kalgutkar \& Jansonius, 2000; Taylor, Krings \& Taylor, 2015). Within Brachysporites, type two spores are most similar to B. atratus Kalgutkar, while type four spores are most similar to B. pyriformis Lange et Smith (Kalgutkar \& Jansonius, 2000). Type three spores are comparable to conidia of the extant magnaporthaceous ascomycete Clasterosporium Schwein. (Kalgutkar \& Jansonius, 2000); the extinct $C$. eocenicum Fritel et Viguier is especially similar to our type three spores, although the latter are slightly smaller. Type five spores are comparable to the conidia of the extant pleosporaceous ascomycete Curvularia Boedijn based on their size, curved shape, and inflated subapical cell (Elsik, 1993).

Overall, the fungal reproductive structures documented on the Todea rhizome are comparable with those of several ascomycete lineages, including Dematiaceae (microsclerotia and two of the spore types), Magnaporthaceae, and Pleosporaceae (Elsik, 1993; Kalgutkar \& Jansonius, 2000; Klymiuk, Taylor \& Taylor, 2013b). Septate hyphae lacking clamp connections frequently found in the vicinity of these reproductive structures are consistent with ascomycete affinities. Given that all this fungal material was found in detritus or very degraded plant material (Fig. 1), these fungi, which were a component of the epiphyte community, were probably saprotrophs, rather than parasites or endophytes. 
233

234

235

236

237

238

239

240

241

242

243

244

245

246

247

248

249

250

251

252

253

254

255

256

257

258

259

260

261

262

263

\section{Coprolites}

Based on their size, shape and texture, the excavations and coprolites were probably produced by oribatid mites (Labandeira, 1998; Kellogg \& Taylor, 2004; McLoughlin and Bomfleur, 2016).

\section{Small spherical structures}

Their perfectly circular shape, tendency to completely fill cells, and variable size indicate that the small, spherical structures are not microorganisms and are probably not of cellular nature. Instead, they probably represent a type of cell content degradation and aggregation due to the fossilization processes, also seen in the Early Devonian Rhynie chert plants (Michael Krings, personal comm., 2017).

\section{Distribution patterns}

The distribution of colonizing organisms and differential preservation of central vs. peripheral tissues in the Todea rhizome indicate that parts of this rhizome were probably alive immediately prior to fossilization. Consistent with this interpretation, vascular tissues near the center of the rhizome are well-preserved and are neither populated by colonizers (Fig. 1) nor degraded (Figure 3A). However, some of the peripheral leaf bases are highly degraded, surrounded by organic detritus (Figure 3A), and richly populated with colonizers (Fig. 1). The leaf bases on one side of the rhizome are particularly degraded, and this region is most densely colonized by epiphytic organisms (Fig. 1). Some leaf bases in this region contain coprolite-filled galleries large enough to adversely affect the physiological functions and structural integrity of these leaves (Figure 3B). Together, these observations indicate that the most degraded and heavily colonized peripheral leaf bases were probably dead at the time of fossilization, whereas the stem and more centrally-located, less degraded leaf bases were probably alive. This distribution of degraded and living tissues is not surprising, since the rhizomes of living Osmundaceae are often surrounded by a mantle of degraded and richly colonized dead leaf bases (Fig. 3C).

The fossil Todea rhizome exhibits dense colonization by a diverse community of epiphytes, which cover it in several kinds of life (Fig. 1), just like extant osmundaceous rhizomes (Fig. 3C). The distribution and frequency of each kind of organism associated with the rhizome 
264 by tissue type (Fig. 2N-O; Table 1) show that most associated organisms are much more

265 abundant in the more degraded region of the rhizome (Fig. 1). Liverworts and fungi in detritus

266 are found primarily external to the fern tissues, and secondarily within some of the most

267 degraded tissues near the periphery of the rhizome (Fig. 1, 2N-O). Coprolites also occur in all

268 types of tissue, as well as externally to some of the most degraded leaf bases, indicating that the

269 arthropods that produced them did not have strong preferences for lignified or parenchymatous

270 tissues (Fig. 1, 2N-O).

271

272 Comparison with the Jurassic community associated with Osmundastrum pulchellum

273 A community of organisms similar to that of the Todea rhizome has been described

274 associated with an exceptionally well preserved Osmundastrum pulchellum Bomfleur, G. Grimm

275 et McLoughlin rhizome from the Jurassic of Sweden (Bomfleur, McLoughlin \& Vajda, 2014;

276 McLoughlin \& Bomfleur, 2016; Bomfleur et al., 2017). Like the Patagonian community, this

277 Jurassic community included fungi, oribatid mites (coprolites) and epiphytic plants. However, in

278 the case of the Osmundastrum pulchellum community, the epiphytic plants are exclusively

279 vascular (lycopsids and ferns), which may indicate that bryophytes had not yet evolved the

280 epiphytic habit during the Jurassic. Additionally, fungal material is more abundant and diverse

281 in the Patagonian rhizome, probably correlated with higher proportions of decomposed tissues.

282 The richness of the communities associated with both of these osmundaceous rhizomes suggests

283 that other permineralized fern rhizomes are likely to yield diverse communities of associated

284 organisms.

285

286

$\underline{\text { Significance of the leafy liverwort fossils }}$

Given the sparse fossil record of liverworts (Oostendorp, 1987; Tomescu, 2016;

Heinrichs et al., 2018; Tomescu et al., 2018), it is not surprising that these tiny epiphytes represent the first report of fossil leafy liverworts from South America. Marchantites hallei Lundblad (Lundblad, 1955), a thalloid liverwort from the Early Cretaceous of Argentina, is the only other unequivocal fossil liverwort known from South America (Oostendorp, 1987; Tomescu et al., 2018). However, three additional compression fossils from the Carboniferous of Bolivia and the Mesozoic of Argentina that lack cellular detail have also been compared with thalloid 
294 liverworts (Jain and Delevoryas, 1967; Cardozo and Iannuzzi, 2004; Coturel and Savoretti, 295 2018).

296 The liverworts described here are also the first epiphytic leafy gametophytes documented 297 in the fossil record outside of amber deposits [see Grolle and Meister (2004), Frahm (2010), and

298 Heinrichs et al. (2018) for reviews of bryophytes preserved in amber]. All other non-amber

299 fossils of epiphytic bryophytes are moss protonemata described on angiosperm leaves

300 (Mägdefrau, 1956; Selkirk, 1974; Barclay et al., 2013).

301

302

$\underline{\text { Importance of understanding epiphyte communities in fossil biotas }}$

303

Today, rich epiphyte communities are found on plants in several biomes, including boreal

304

305

306

307

308

309

310

311

312

313

314

315

316

317

318

319

320

321

322

323

324

forests (McCune, 1993), tropical lowland rainforests (Cornelissen and Ter Steege, 1989), and tropical montane forests (Wolf, 1993a,b). In these ecosystems, epiphyte communities provide critical ecological services, including soil production within forest canopies (Enloe et al., 2006), increased nutrient input (Coxson and Nadkarni, 1995), and increased water storage (Pócs, 1980; Vaneklaas and van Ek, 1990; Pykper et al., 2005). Thus, epiphyte communities significantly influence the ecology of their host plants. The makeup of epiphyte communities is diverse in the modern biota and co-varies dramatically with forest composition. In boreal forests of Pacific Northwest North America, lichens and mosses may dominate (McCune, 1993), whereas bromeliads and orchids may dominate epiphyte communities in a mid-elevation rainforest of central Mexico (Hietz and Hietz-Seifert, 1995). The evolution of the deeply divergent epiphyte communities in these biomes is critical for understanding the ecology and evolutionary history of the forests themselves. However, our understanding of epiphyte community composition in the distant past is poor and based on a small number of examples (e.g., Rothwell, 1991; Rössler, 2000; McLoughlin \& Bomfleur, 2016).

Knowledge of complex epiphyte communities in fossil plant assemblages, including detailed insight into component communities like those of the Patagonian rhizome, is needed to paint a more complete picture of life in the geologic past and contextualize the evolution of epiphyte communities. Past epiphyte communities probably provided the same kinds of ecosystem services as those of the modern biota because these functions are independent of epiphyte community structure. Thus, attempts to understand the ecology of these fossil biotas without epiphytes ignore a critical component of the ecosystem. Similarly, an understanding of 
325 ancient communities is required to place their modern counterparts in an evolutionary framework

326 (Gerhold et al., 2018).

327

328

329

330

Osmundaceous rhizomes as a model system for understanding epiphyte community structure

In principle, an appropriate host organism could provide a model system to track epiphytes through geologic time, and from this we could determine when certain groups evolved the epiphytic habit (e.g., modern leptosporangiate ferns, lycophytes, bryophytes, angiosperms) and how epiphyte community structure varied between different forest types in the distant past. A model system would also allow for rigorous testing of hypotheses on the evolution of epiphytic leafy liverworts (Feldberg et al., 2014), lycophytes, and filicalean ferns (Lovis, 1977; Schneider et al., 2004). Such a host organism would need to meet four requirements: (1) a morphology that facilitates colonization by epiphytes; (2) morphological stasis over a wide stratigraphic range; (3) widespread geographic distribution; and (4) abundance in the fossil record.

Permineralized osmundaceous rhizomes satisfy these requirements. (1) The leaf bases found at the periphery of osmundaceous rhizomes have a rich microtopography that facilitates colonization by epiphytes. Indeed, living osmundaceous fern rhizomes are often covered in epiphytes (Fig 3C). (2) Osmundaceous ferns have been in morphological stasis since the Permian (> 250 million years; Miller, 1971; Bomfleur et al., 2017). (3) Osmundaceae were widespread geographically in the geologic past (Miller, 1971; Bomfleur et al., 2017). (4) Osmundaceous ferns arguably have the richest fossil record of any living fern lineage (Arnold, 1964; Miller, 1971; Tidwell and Ash, 1994; Bomfleur et al., 2017). Additionally, living osmundaceous ferns allow direct comparison of the fossil epiphyte communities to their extant counterparts.

To date, permineralized osmundaceous rhizomes have yielded evidence for plant interactions with invertebrates (Schopf, 1978; Tidwell \& Clifford, 1995; McLoughlin \& Bomfleur, 2016) and fungi (Kidston \& Gwyne-Vaughan, 1907; Gould, 1970; McLoughlin \& Bomfleur, 2016). These occurrences confirm that osmundaceous rhizomes were important hosts for epiphyte communities in ancient ecosystems, just as they are today. Because permineralized osmundaceous rhizomes represent a well-populated epiphyte niche that has remained unchanged 
355

356

357

358

359

360

361

362

363

364

365

366

367

368

369

370

371

372

373

374

375

376

377

378

379

380

381

382

383

384

385

over time and space and have a rich fossil record reaching into the Permian, they provide a paleoecological model system for exploring epiphyte community structure and evolution.

\section{Conclusions}

The complex community of organisms associated with an early Eocene osmundaceous fern rhizome from Patagonia allows a glimpse of a tiny, ancient epiphyte community centered around a single host plant. This community is surprisingly diverse and includes the first fossilized leafy liverworts in South America, also marking the only fossil record of leafy bryophyte epiphytes known outside of amber deposits; several types of fungal hyphae and spores; microsclerotia with possible affinities in several ascomycete families; and coprolites produced by oribatid mites.

Understanding of complex epiphyte communities in fossil plant assemblages is needed to accurately understand ecological networks within extinct ecosystems and to unearth the evolutionary history of extant epiphytes. In the fossil record, complex epiphyte communities on plants have only been characterized in uncommon instances (e.g., the petrified forest of Chemnitz, Germany; Rössler, 2000). In contrast to these rare occurrences, fossil osmundaceous ferns and the communities they may harbor are widespread geographically and stratigraphically (Stewart \& Rothwell, 1993; Taylor, Taylor \& Krings, 2009). Osmundaceous ferns can be traced back into the Paleozoic (Miller, 1967, 1971; Stewart \& Rothwell, 1993; Taylor, Taylor \& Krings, 2009; Bomfleur et al., 2017), a time when terrestrial ecological networks were becoming canalized (DiMichele et al., 1992). Furthermore, osmundaceous morphology has been in stasis since the Paleozoic (Eames, 1936; Stewart \& Rothwell, 1993; Bomfleur, McLoughlin \& Vajda, 2014). As such, osmundaceous rhizomes represent a distinctive ecological niche, unchanged since the Permian, and act as hosts for epiphyte communities comprised of plants, animals, and fungi. These communities can also be studied in the modern biota and can be sampled systematically and consistently across all occurrences, fossil and extant. Because of the scale of the organisms (centimeter to decimeter), entire in situ tiny epiphyte communities can be studied directly in fossil specimens. Thus, osmundaceous rhizomes represent an ecological niche that has remained unchanged over time and provide a paleoecological model system for exploring epiphyte community structure across geologic time and space. Given the diversity of epiphytes associated with osmundaceous rhizomes from the Huitrera Formation and the Jurassic of Sweden 
386 (McLoughlin \& Bomfleur, 2016), as well as the abundance of osmundaceous rhizomes in the 387 fossil record (Miller, 1967, 1971; Taylor, Taylor \& Krings, 2009; Bomfleur et al., 2017), we 388 predict that continued exploration will reveal additional aspects of the biotic networks centered

389 390

391

392

393

394

395

396

397

398

399

400

401

402

403

404

405

406

407

408

409

410

411

412

413

414

415

416 around these important repositories of ecological data from the geologic past.

\section{Acknowledgements}

The authors thank Carla J. Harper, (University of Kansas, Lawrence, Kansas) and Terry Henkel (Humboldt State University, Arcata, California) for help identifying fungal material associated with the fern rhizome, Michael Krings (Ludwig-Maximilians-Universität München, Germany) for help determining the origin of the degraded cell contents, Benjamin Bomfleur (Universität Münster, Germany) for identifying the host fern, Eduardo Ruigomez (Museo Paleontológico Egidio Feruglio, Trelew, Argentina) for facilitating work in the MPEF collections, and Russell Bryan for assistance rendering Figure 2N. This study was initiated during ACB's and AMFT's visit to Museo Paleontologico Egidio Feruglio as part of a collaboration funded by US National Science Foundation (NSF) grant IIA-1322504 (to AMFT). Additional support came from an NSF Graduate Research Fellowship (to ACB) and NSF grants DEB-1556666 and EAR 1925755 (to PW).

\section{References}

Aragón, E., and Mazzoni, M.M. (1997). Geología y estratigrafía del complejo volcánico piroclástico del Río Chubut medio (Eoceno), Chubut, Argentina. Rev. Asoc. Geol. Argent. $52,243-256$.

Arnold, C.A. (1964). Mesozoic and Tertiary fern evolution and distribution. Mem. Torrey Bot. Club 21, 58-66.

Barclay, R.S., McElwain, J.C., Duckett, J.G., Van Es, M.H., Mostaert, A.S., Pressel, S., and Sageman, B.B. (2013). New methods reveal the oldest known fossil epiphyllous moss: Bryiidites utahensis gen. et sp. nov. (Bryiidae). Am. J. Bot. 100, 2450-2457.

Berry, E.W.A. (1925). Miocene flora from Patagonia. Johns Hopkins Univ. Stud. Geol. 6, 183251.

Bomfleur, B., and Escapa, I.H. (2019). A silicified Todea trunk (Osmundaceae) from the Eocene of Patagonia. Pal. Z. 93, doi: 10.1007/s12542-019-00479-6 
417 Bomfleur, B., McLoughlin, S., and Vajda, V. (2014). Fossilized nuclei and chromosomes reveal 418180 million years of genomic stasis in royal ferns. Science 343, 1376-1377.

419

420

421

422

423

424

425

426

427

428

429

430

431

432

433

434

435

436

437

438

439

440

441

442

443

444

445

446

447

Bomfleur, B., Grimm, G.W., McLoughlin, S. (2017). The fossil Osmundales (Royal Ferns) - a phylogenetic network analysis, revised taxonomy, and evolutionary classification of anatomically preserved trunks and rhizomes. Peer J 5, e3433.

Cardoso, N., and Iannuzzi, R. (2004). Nova Briófira do Carbonífero Inferior da Bolívia. Rev. Bras. Paleontolog. 7, 111-116.

Carvalho, M.R., Wilf, P., Hermsen, E.J., Gandolfo, M.A., Cúneo, N.R., and Johnson, K.R. (2013). First record of Todea (Osmundaceae) in South America, from the early Eocene paleorainforests of Laguna del Hunco (Patagonia, Argentina). Am. J. Bot. 100, 18311848.

Cornelissen, J.H., Ter Steege, H. (1989). Distribution and ecology of epiphytic bryophytes and lichens in dry evergreen forest of Guyana. J. Trop. Ecol. 5, 131-150.

Coturel, E.P., and Savoretti, A. (2018). Hepaticites (Marchantiophyta) in the Lower Permian Arroyo Totoral Formation (La Rioja Province, Argentina). Ameghiniana 55, 350-355.

Coxson, D.S., and Nadkarni, N.M. (1995). Ecological roles of epiphytes in nutrient cycles of forest ecosystems (San Francisco: Academic Press).

DiMichele, W.A., Hook, R.W., Beerbower, R., Boy, J.A., Gastaldo, R.A., Hotton N., Phillips, T.L., Scheckler, S.E., Shear, W.A., and Sues, H.D. (1992). Paleozoic terrestrial ecosystems. In: Behrensmeyer, A.K., Damuth, J.D., DiMichele, W.A., Potts, R., Sues, H.D., Wing, S.L., eds. Terrestrial Ecosystems through Time. (Chicago: University of Chicago Press).

Eames, A.J. (1936). Morphology of Vascular Plants. Lower Groups (Psilophytales to Filicales) (New York: McGraw Hill Book Company).

Elsik, W.C. (1993). The morphology, taxonomy, classification and geologic occurrence of fungal palynomorphs. American Association of Stratigraphic Palynologists Short Course, October 23-24, Baton Rouge, LA (Dallas: American Association of Stratigraphic Palynologists Foundation).

Enloe, H.A., Graham, R.C., and Sillett, S.C. (2006). Arboreal histosols in old-growth redwood forests canopies, northern California. Soil Sci. Soc. Am. J. 70, 408-418.

Esau, K. (1965). Plant Anatomy, Second Edition (New York: John Wiley and Sons Inc.). 
448 Feldberg, K., Schneider, H., Stadler, T., Schäfer-Verwimp, A., Schmidt., A.R., and Heinrichs, J. 449 (2014). Epiphytic leafy liverworts diversified in angiosperm-dominated forests. Sci. Rep. 450 4, DOI: 10.1038/srep05974.

451 Frahm, J.P. (2010). Die Laubmoosflora des Baltischen Bernsteinwaldes. (Jena: Weissdorn452 Verlag).

453 Gandolfo, M.A., Hermsen, E.J., Zamaloa, M.C., Nixon, K.C., González, C.C., Wilf, P., Cúneo, 454 N.R., and Johnson, K.R. (2011). Oldest known Eucalyptus macrofossils are from South $455 \quad$ America. PLoS One 6, e21084.

456 Gerhold, P., Carlucci, M.B., Procheş, S., and Prinzing, A. 2018. The deep past controls the 457 phylogenetic structure of present, local communities. Annu. Rev. Ecol. Evol. Syst. 49, $458 \quad 477-497$.

459 Gosses, J. (2006). Stratigraphy and ${ }^{40} \mathrm{Ar} /{ }^{39} \mathrm{Ar}$ geochronology of the Laguna del Hunco 460 Formation: a lacustrine and sub-aerial caldera moat formation M.S. Thesis, Univ. 461 Wisconsin, Madison.

462 Gosses, J., Carroll, A., Aragón, E., and Singer, B. (2006). The Laguna del Hunco Formation; 463 lacustrine and sub-aerial caldera fill, Chubut Province, Argentina. Geological Society of 464 America Annual Meeting, Denver, Abstracts with Programs 38, 502.

465 Gould, R.E. (1970). Palaeosmunda, a new genus of siphonostelic osmundaceous trunks from the $466 \quad$ Upper Permian of Queensland. Palaeontology 13, 10-28.

467 Grolle, R., and Meister, K. (2004). The liverworts in Baltic and Bitterfeld Amber. Weissdorn, 468 Jena.

469

Heinrichs, J., Feldberg, K., Bechteler, J., Regalado, L., Renner, M.A.M., Schäfer-Verwimp, A., Gröhn, C., Müller, P., Schneider, H., Krings, M. (2018). A comprehensive assessment of the fossil record of liverworts in amber. In: Krings, M., C.J. Harper, N.R. Cúneo, and G.W. Rothwell (eds.) Transformative paleobotany: Papers to commemorate the life and legacy of Thomas N. Taylor. Academic Press, San Francisco.

Hietz, P., and Hietz-Siefert, U. (1995). Composition and ecology of vascular epiphyte communities along an altitudinal gradient in central Veracruz, Mexico. J. Veg. Sci. 6, 487498.

Jain, R.K., and Delevoryas, T. (1967). A Middle Triassic Flora from the Cacheuta Formation, Minas de Petroleo, Argentina. Palaeontology 10, 564-589. 
479 Kalgutkar, R.M., and Jansonius, J. (2000). Synopsis of fossil fungal spores, mycelia and 480 fructifications. American Association of Stratigraphic Palynologists Contributions 39

481

482

483

484

485

486

487

488

489

490

491

492

493

494

495

496

497

498

499

500

501

502

503

504

505

506

507

508 509

(Dallas: American Association of Stratigraphic Palynologists Foundation).

Kellogg, D.W., and Taylor, E.L. (2004). Evidence of oribatid mite detritivory in Antarctica during the late Paleozoic and Mesozoic. J. Paleontol. 78, 1146-1153.

Kidston, R., Gwynne-Vaughan, D.T. (1907). XXVII.- On the fossil Osmundaceæ. Trans. R. Soc. Edinb. 45, 759-780.

Klymiuk, A.A., Taylor, T.N., and Taylor, E.L. (2013b). Paleomycology of the Princeton Chert II. Dark-septate fungi in the aquatic angiosperm Eorhiza arnoldii indicate a diverse assemblage of root-colonizing fungi during the Eocene. Mycologia 105, 1100-1109.

Kuiper, K.F, Deino, A., Hilgen, F.J., Krijgsman, W., Renne, P.R., Wijbrans, J.R. (2008). Synchronizing rock clocks of Earth history. Science 320, 500-504.

Labandeira, C.C. (1998). Early history of arthropod and vascular plant associations. Ann. Rev. Earth Planet. Sci. 26, 329-377.

Lovis, J.D. (1977). Evolutionary patterns and processes in ferns. In: Preston, R.D., Woolhouse, H.W. (eds.) Advances in Botanical Research. Academic Press, London.

Lundblad, B. (1955). Contributions to the geological history of the Hepaticae: On a fossil member of the Marchantilineae from the Mesozoic plant-bearing deposits near Lago San Martin, Patagonia (Lower Cretaceous). Bot. Not. 108, 22-39.

Mägdefrau, K. (1956). Paläobiologie der Pflanzen, Third Edition. (Jena: Gustav Fischer Verlag). McCune, B. (1993). Gradients in epiphyte biomass in three Pseudotsuga-Tsuga forests of different ages in western Oregon and Washington. Bryologist 96, 405-411.

McLoughlin, S., and Bomfleur, B. (2016). Biotic interactions in an exceptionally well preserved osmundaceous fern from the Early Jurassic of Sweden. Palaeogeogr. Palaeoclimatol. Palaeoecol. 464, 86-96.

Miller, C.N. (1967). Evolution of the fern genus Osmunda. Contrib. Univ. Mich. Mus. Paleontol. 21, 139-203.

Miller, C.N. (1971). Evolution of the fern family Osmundaceae based on anatomical studies. Contrib. Univ. Mich. Mus. Paleontol. 23,105-169.

Oostendorp, C. (1987). The bryophytes of the Palaeozoic and the Mesozoic. Bryophyt. Bibl. 34, $1-112$.

Peer] reviewing PDF | (2017:11:21919:2:0:NEW 7 Nov 2019) 
510 Petersen, C.S. (1946). Estudios geológicos en la región del Río Chubut medio. Bol. Dir. Minas

$511 \quad$ Geol. 59, 1-137.

512 Pócs, T. The epiphytic biomass and its effect on the water balance of two rain forest types in the 513 Uluguru mountains (Tanzania, east Africa). Acta Bot. Acad. Sci. Hungaria 26, 143-167.

514 Pypker, T.G., Unsworth, M.H., and Bond, B.J. (2006). The role of epiphytes in rainfall

515 interception by forests in the Pacific Northwest. I. Laboratory measurements of water 516 storage. Can. J. For. Res. 36, 809-818.

517 Rössler, R. (2000). The late Palaeozoic tree fern Psaronius - an ecosystem unto itself. Rev. 518 Palaeobot. Palynol. 108, 55-74.

519 Rothwell, G.W. (1991). Botryopteris forensis (Botryopteridaceae), a trunk epiphyte of the tree 520 fern Psauronius. Am. J. Bot. 78, 782-788.

521 Schofield, W.B. (1985). Introduction to Bryology (Caldwell: The Blackburn Press).

522 Schneider, H., Schuettpelz, Pryer, K.M., Cranfill, R., Magallón, S., and Lupia, R. (2004). Ferns 523 diversified in the shadow of angiosperms. Nature 428, 553-557.

524 Schopf, J.M. (1978). An unusual osmundaceous specimen from Antarctica. Can. J. Bot. 56, 525 3083-3095.

526 Selkirk, D.R. (1974). A fossil epiphyllous moss from the Australian Miocene. Bryologist 77, $527 \quad 249-250$.

528 Steel, J.B., and Bastow Wilson, J. (2003). Which is the phyte in epiphyte? Folia Geobot. 38, 9752999.

530 Stewart, W.N., and Rothwell, G.W. (1993). Paleobotany and the Evolution of Plants (New York: 531 Cambridge University Press).

532 Taylor, T.N., Taylor, E.L., and Krings, M. (2009). Paleobotany. The Biology and Evolution of 533 Fossil Plants, Second Edition (San Francisco: Academic Press).

534 Taylor, T.N., Krings, M., and Taylor, E.L. (2015). Fossil Fungi. (San Francisco: Academic 535 Press).

536 Tejedor, M.F., Goin, F.J., Gelfo, J.N., López, G., Bond, M., Carlini, A.A., Scillato-Yané, G.J, 537 Woodburne, M.O., Chornogubsky, L., Aragón, E., Reguero, M.A., Czaplewski, N.J., 538 Vincon, S., Martin, G.M., and Ciancio, M.R. (2009) New early Eocene mammalian fauna 539 from western Patagonia, Argentina. Am. Mus. Novit. 3638, 1-43. 
540 Tidwell, W.D., and Ash, S.R. (1994). A review of selected Triassic to Early Cretaceous ferns. J. $541 \quad$ Plant Res. 107, 417-442.

542 Tidwell, W.D., and Clifford, H.T. (1995). Three new species of Millerocaulis (Osmundaceae)

543 from Queensland, Australia. Aust. Syst. Bot. 8, 667-685.

544 Tomescu, A.M.F. (2016). The Early Cretaceous Apple Bay flora of Vancouver Island: a hotspot 545 of fossil bryophyte diversity. Botany 94, 683-695.

546 Tomescu, A.M.F., Bomfleur, B., Bippus, A.C., and Savoretti, M. A. (2018). Why are bryophytes 547 so rare in the fossil record? A focus on taphonomy and fossil preservation. In: Krings, M., 548 C.J. Harper, N.R. Cúneo, and G.W. Rothwell (eds.) Transformative paleobotany: Papers to commemorate the life and legacy of Thomas N. Taylor. Academic Press, San Francisco.

550 551

552

553

554

555

556

557

558

559

560

561

562

563

564

565

566

567

568

569

Veneklaas, E.J., and Van Ek, R. (1990). Rainfall interception in two tropical montane rain forests, Colombia. Hydrol. Process. 4, 311-326.

Wilf, P. (2012). Rainforest conifers of Eocene Patagonia: attached cones and foliage of the extant Southeast Asian and Australasian genus Dacrycarpus (Podocarpaceae). Am. J. Bot. 99, 562-584.

Wilf, P., Cúneo, N.R., Johnson, K.R., Hicks, J.F., Wing, S.L., and Obradovich, J.D. (2003). High plant diversity in Eocene South America: evidence from Patagonia. Science 300, 122-125.

Wilf, P., Johnson, K.R., Cúneo, N.R., Elliot Smith, M., Singer, B.S., and Gandolfo, M.A. (2005a). Eocene plant diversity at Laguna del Hunco and Río Pichileufú, Patagonia, Argentina. Am. Nat. 165, 634-650.

Wilf, P., Labandeira, C.C., Johnson, K.R., and Cúneo, N.R. (2005b). Richness of plant-insect associations in Eocene Patagonia: A legacy for South American biodiversity. Proc. Nat. Acad. Sci. USA 102, 8944-8948.

Wilf, P., Cúneo, N.R., Escapa, I.H., Pol, D., and Woodburne, M.O. (2013). Splendid and seldom isolated: the paleobiogeography of Patagonia. Ann. Rev. Earth Planet. Sci. 41, 561-603.

Wilf, P., Escapa, I.H., Cúneo, N.R., Kooyman, R.M., Johnson, K.R., and Iglesias, A. (2014). First South American Agathis (Araucariaceae), Eocene of Patagonia. Am. J. Bot. 101, 156-179.

Wilf, P., Carvalho, M.R., Gandolfo, M.A. and Cúneo, N.R. (2017). Eocene lantern fruits from Gondwanan Patagonia and the early origins of Solanaceae. Science 355, 71-75. 
570 Wolf, J.H.D. (1993a). Epiphyte communities of tropical montane rain forests in the northern

571 Andes I. Lower montane communities. Phytocoenologia 22, 1-52.

572 Wolf, J.H.D. (1993b). Diversity patterns and biomass of epiphytic bryophytes and lichens along 573 an altitudinal gradient in the northern Andes. Ann. Mo. Bot. Gard. 80, 928-960. 


\section{Table $\mathbf{1}$ (on next page)}

Distribution of types of organisms colonizing the Patagonian osmundaceous rhizome (data point counts). 
1 Table 1. Distribution of types of organisms colonizing the Patagonian osmundaceous rhizome

2 (data point counts).

3

\begin{tabular}{|c|c|c|c|c|c|}
\hline Fern tissue type & Liverworts & $\begin{array}{l}\text { Fungi in } \\
\text { detritus }\end{array}$ & Coprolites & $\begin{array}{l}\text { Gymnosperm } \\
\text { root }\end{array}$ & $\begin{array}{l}\text { Degraded cell } \\
\text { content }\end{array}$ \\
\hline Vascular tissue & 0 & 1 & 8 & 0 & 2 \\
\hline Fiber ring & 1 & 4 & 18 & 0 & 4 \\
\hline $\begin{array}{l}\text { Parenchymatous } \\
\text { mesophyll }\end{array}$ & 1 & 77 & 26 & 0 & 1 \\
\hline $\begin{array}{l}\text { External to fern } \\
\text { tissue }\end{array}$ & 20 & 88 & 7 & 1 & 0 \\
\hline Total & 22 & 170 & 59 & 1 & 7 \\
\hline
\end{tabular}

4 


\section{Figure 1}

Component communities associated with a Todea rhizome from the early Eocene of Patagonia, specimen MPEF-Pb 9299.

Composite image of cross section through the rhizome with vascular cylinder at center and numerous leaf traces in a helical pattern. The distribution of associated organisms is mapped in green (for leafy liverworts), light blue (fungi in detritus), purple (coprolites); arrowhead gymnosperm root. Note denser colonization of the more degraded part of the rhizome at right. Scale bar $=1 \mathrm{~cm}$. 


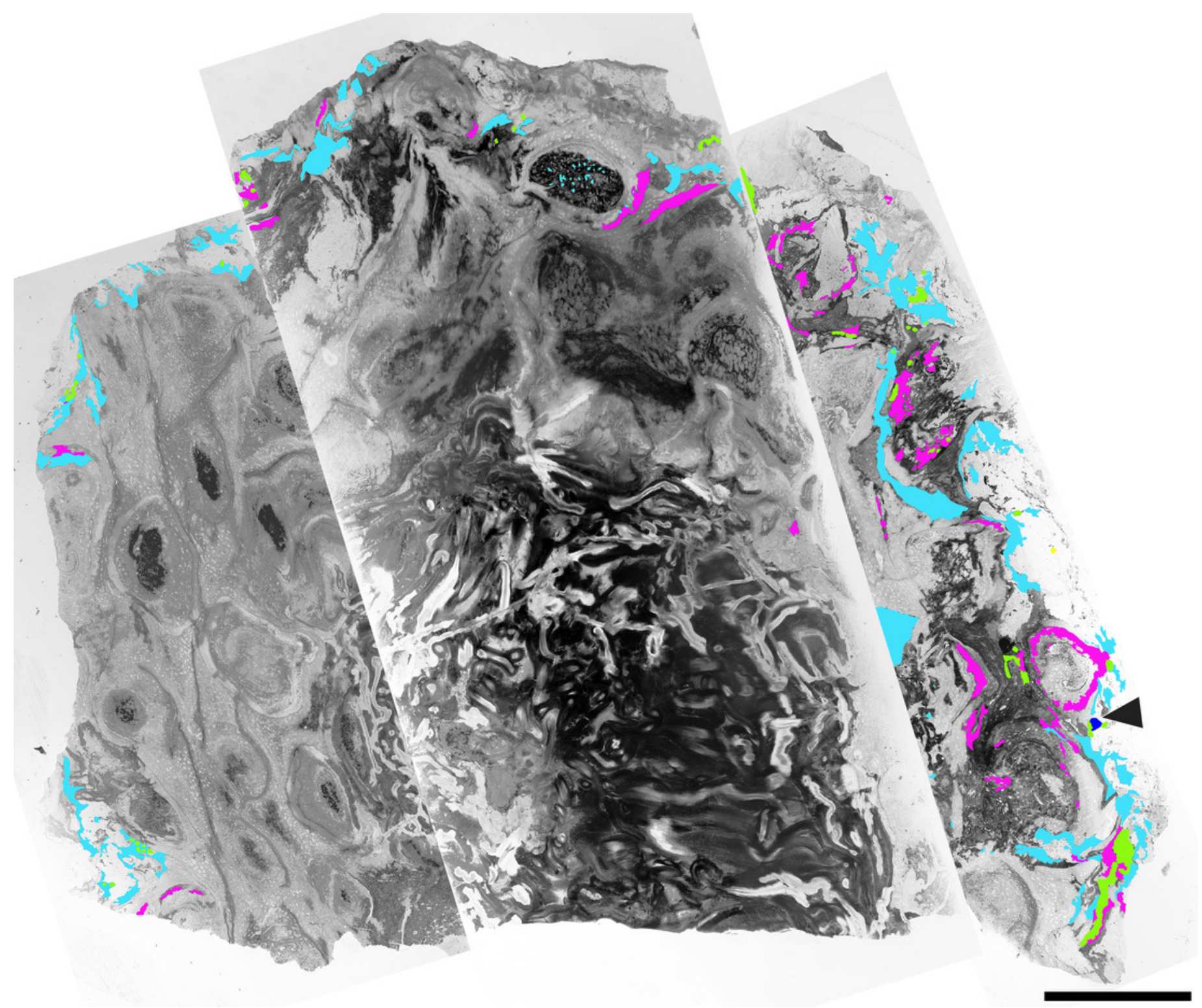




\section{Figure 2}

Figure 2. Diversity and distribution of organisms associated with the Patagonian Todea rhizome.

(A) Longitudinal section of leafy liverwort gametophyte, showing two-ranked arrangement of ecostate leaves. (B) Cross sections of five branches of a leafy liverwort shoot. Note lack of lignified tissues in the stems and thin, ecostate leaves. (C) Oblique longitudinal section of a leafy liverwort stem (bottom) with two diverging branches. (D) Cross section of gymnosperm root with diarch protostele and secondary xylem. (E) Coprolite-filled gallery in osmundaceous leaf base. (F) Cerebriform microsclerotium in detritus around rhizome. (G) Three-celled stalked spores in detritus around rhizome (H) Seven to eight-celled, stalked spores in detritus around rhizome. (I) Five-celled spores in detritus around rhizome. (J) Three-celled, stalked, spatulate spores in detritus around rhizome. (K) Three-celled, stalked, elliptical spores in detritus around rhizome. (L) Septate hyphae in detritus around the rhizome. (M) Circular structures of variable size filling a plant cell, thought to be the result of cell content degradation and aggregation during fossilization (N) Tissues of an osmundaceous leaf base diagrammed (0)Frequency of occurrence by tissue (same color coding as $\mathrm{N}$ ) of each type of organismic remains associated with the Patagonian rhizome. See also Table 1. Scale bars: AE $250 \mu \mathrm{m} ; \mathrm{F} 25 \mu \mathrm{m}$; G-K, M $5 \mu \mathrm{m}$; L $2.5 \mu \mathrm{m}$. 

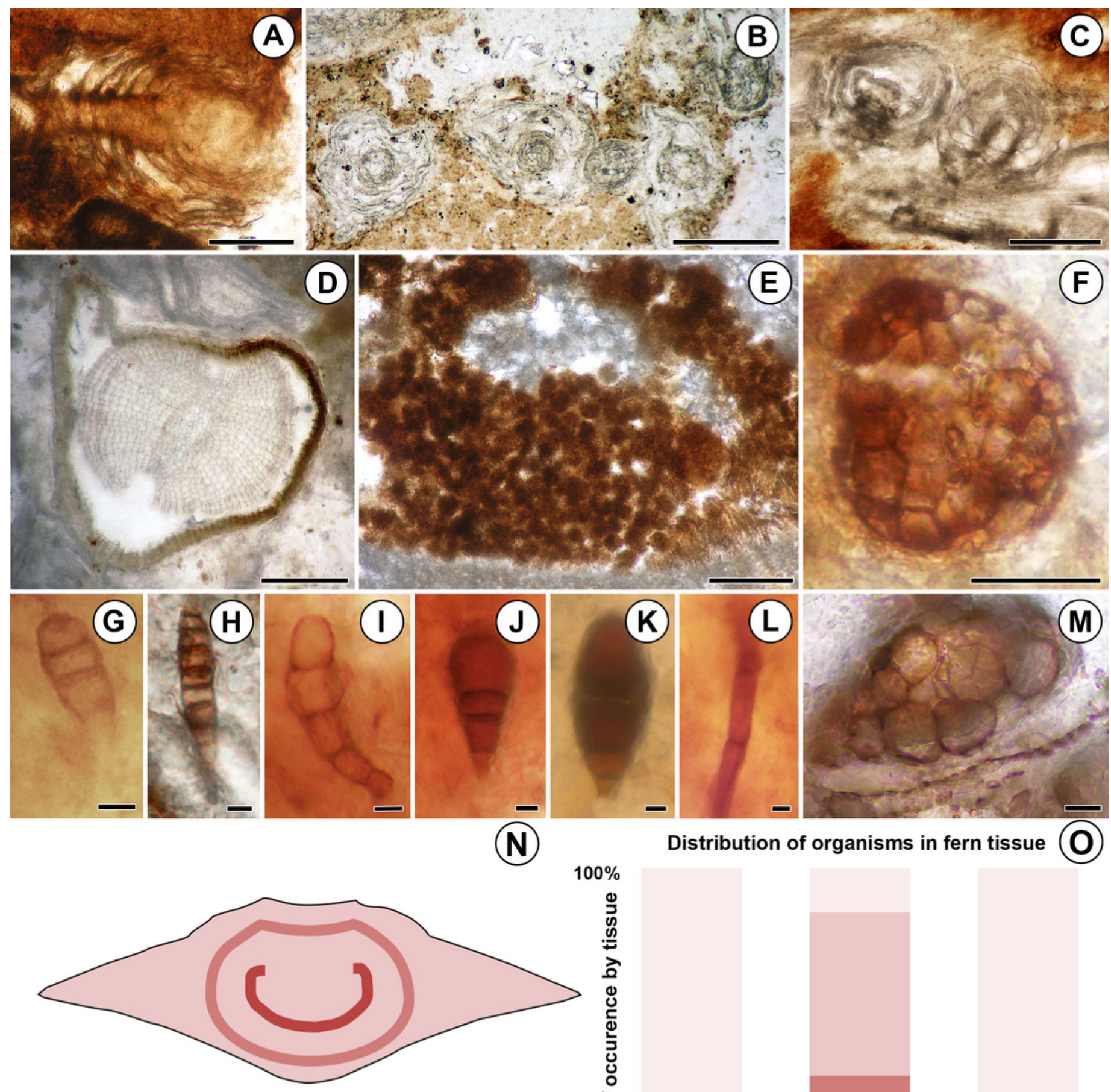

$100 \%$

External to fern tissue

Parenchymatous mesophyll

Fiber band

Vascular tissue

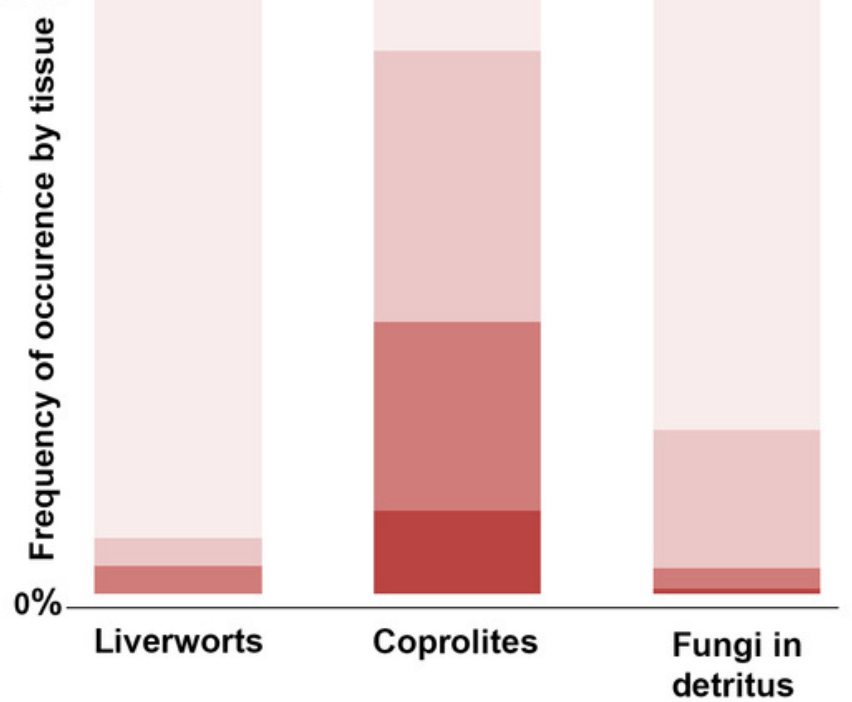




\section{Figure 3}

Preservation of the Patagonian Todea rhizome and densely colonized extant Osmunda L. rhizome.

(A) Partial cross section of the rhizome shown in Fig. 1 magnified to show gradient in preservation from periphery to center. (B) Cross section of a degraded leaf base with extensive coprolite-filled galleries. Coprolite-filled galleries are highlighted in purple. (C) ExtantOsmunda regalisL. rhizome in the Humboldt State University greenhouse showing abundant epiphyte colonization. Scale bars: A 5 mm; B $1 \mathrm{~mm}$. 


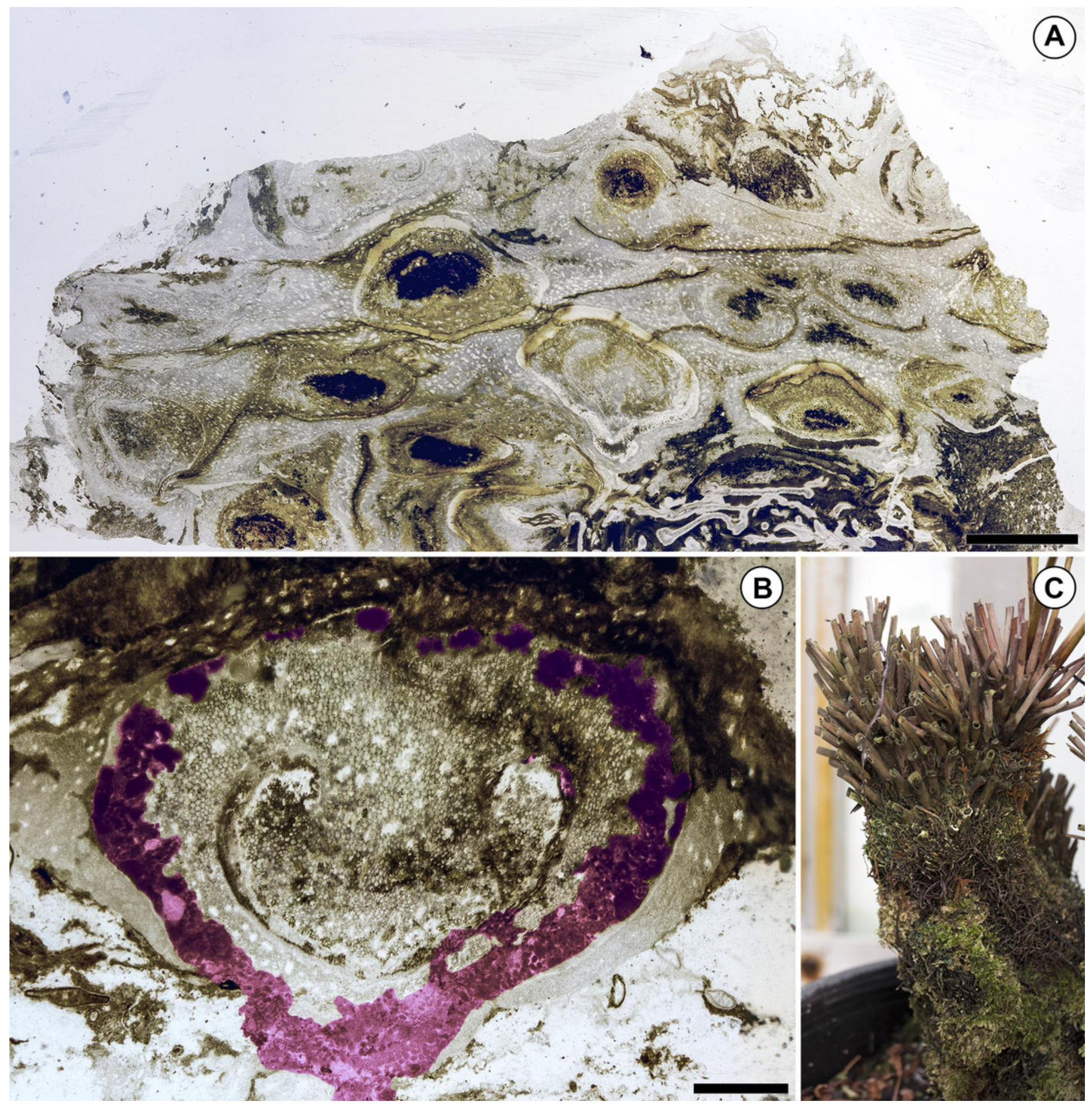

